\title{
New evidence of paleodrainage as an indicator of morphological evolution in Amazon coast, North Cape, Brazil
}

Jardim, K.A., Universidade Federal Fluminense/UFF;

Santos, V.F dos., Instituto de Pesquisas Científicas Tecnológicas do Estado do Amapá/IEPA;

Figueiredo Jr., A.G.F., Universidade Federal Fluminense/UFF.

Copyright 2021, SBGf - Sociedade Brasileira de Geofísica.

This paper was prepared for presentation during the $17^{\text {th }}$ International Congress of the Brazilian Geophysical Society held in Rio de Janeiro, Brazil, 8-11 November 2021.

Contents of this paper were reviewed by the Technical Committee of the $17^{\text {th }}$ International Congress of the Brazilian Geophysical Society and do not necessarily represent any position of the SBGf, its officers or members. Electronic reproduction or storage of any part of this paper for commercial purposes without the written consent of the Brazilian Geophysical Society is prohibited.

\begin{abstract}
The coastal plain north of the mouth of the Amazon River has an extraordinary network of paleodrainages. These features represent large changes in the regional drainage system, the result of colmatation processes, local and regional tectonic and neotectonic movements, and relative sea level change. Such systems are important because they condition the evolution of habitats and are indicators of regional changes. This work presents new evidence of paleodrainages in the Northern Cape region, using radar images from the $X, L$, and $P$ bands. The images were analyzed using the photointerpretation method from the elements of texture, shape, color, and pattern. Geomorphological variables (morphology and morphochronology) were used for the extraction of the paleo features mapped in a Geographic Information System (SIG). A map of the regional paleomorphology framework is originated. The paleo features are marked by extensive drainages in meandering shapes, with levees covered by floodplain forests, which shelter the rich biodiversity of fauna and flora. Drainages have a maximum length of up to $50 \mathrm{~km}$ and a width of up to $4 \mathrm{~km}$. They are grouped into three major paleodrainages systems: NW, SW, and SE which represent records of ancient river systems flowed across the coastal plain towards the Atlantic Ocean. The relationships of morphology and morphochronology between paleo features correlated with the literature and stratigraphic data indicate a recent process (Holocene) of obstruction of this drainage network in the Amazonian coastal plain. They also represent new evidence of paleodrainages that can help to clarify the evolutionary history of this region and consequently understand the distribution of its habitats.
\end{abstract}

